University of New Hampshire

University of New Hampshire Scholars' Repository

Fall 2003

\title{
Accountability And Ethics: Reconsidering the Relationships
}

Melvin J. Dubnick

University of New Hampshire - Main Campus, Mel.dubnick@UNH.edu

Follow this and additional works at: https://scholars.unh.edu/polisci_facpub

Part of the Political Science Commons, and the Public Affairs, Public Policy and Public Administration Commons

\section{Recommended Citation}

Dubnick, M. Accountability And Ethics: Reconsidering the Relationships, International Journal of Organization Theory and Behavior, 6, no. 3 (Fall, 2003): 405-441.

This Article is brought to you for free and open access by the Political Science at University of New Hampshire Scholars' Repository. It has been accepted for inclusion in Political Science Scholarship by an authorized administrator of University of New Hampshire Scholars' Repository. For more information, please contact Scholarly.Communication@unh.edu. 


$\begin{array}{llrrr}\text { INTERNATIONAL } & \text { JOURNAL OF ORGANIZATION } & \text { THEORY } & \text { AND } \\ \text { BEHAVIOR, } 6(3), & 405-441 & & \text { FALL } 2003\end{array}$

\title{
ACCOUNTABILITY AND ETHICS: RECONSIDERING THE RELATIONSHIPS
}

\author{
Melvin J. Dubnick*
}

\begin{abstract}
While a relationship between accountability and ethics has long been assumed and debated in Public Administration, the nature of that relationship has not been examined or clearly articulated. This article makes such an effort by positing four major forms of accountability (answerability, blameworthiness, liability and attributability) and focusing on the ethical strategies developed in response to each of these forms.
\end{abstract}

\section{INTRODUCTION}

The relationship between "accountability" and "ethics" has long been a concern among students of public administration. Accountability has traditionally been regarded as the means used to control and direct administrative behavior by requiring "answerability" to some external authority. It has deep roots in American constitutional history, and can be linked to the principles implicit in the Magna Carta as well as our system of checks and balances. In public administration, ethics has most often been associated with standards of responsible behavior and professional integrity in light of the growth of the administrative state and the expansion of discretionary powers to public sector bureaucracies.

Issues about the relationship between the accountability and ethics were central to the Friedrich-Finer debate of the early 1940s - one of core debates that set the intellectual agenda for American public administration during the Cold War era. In a 1940 essay, Friedrich (1940) argued that the traditional means (e.g., oversight and control) for

* Melvin J. Dubnick, Ph.D., is a professor, Department of Political Science and the Graduate Department of Public Administration, Rutgers University Newark. His research interests are in the areas of accountability, ethics, civics education and the role of narratives in the public sphere.

Copyright (c) 2003 by PrAcademics Press 
holding administrators accountable were ineffective and unnecessary. It was reasonable, he contended, to defer to the judgment of administrators whose sense of professional responsibility and loyalty could be trusted when they carried out public policy in the national interest. In response, Finer (1941) reasserted the widely held view that, despite the greater sense of professional responsibility among today's administrators, democracy still requires enhanced public control and direction of administrative agents.

That exchange was - and remains - the classic expression of the conventional relationship between ethics and accountability in public administration (Burke, 1986; Harmon, 1995; Gruber, 1987; McSwite, 1997). Fundamental to that view is the assumption that the commitment of modern administrators to conduct themselves responsibly (i.e., ethically, in accord with "democratic morality") was not sufficient to insure that the will of the people would be carried out. Accountability, in the form of external (i.e., democratic) constraints and controls, was necessary as well. Accountability mechanisms were required to render the decisions and behavior of public officials responsible, not merely in the legal, political or bureaucratic senses of that term, but morally as well (Appleby, 1952; Gilbert, 1959; Marx, 1949). Ethical behavior, in short, required the presence of external accountability mechanisms in all their various forms.

Does accountability foster ethical or morally responsible behavior? Despite considerable scholarship devoted to the examination of efforts to control the bureaucracy through various accountability mechanisms (Aberbach, 1990; Balla, 1998; Calvert, McCubbins \& Weingast 1989; Harris, 1964; Hood, James \& Scott, 2000; Kettl, 1992; Light, 1993; McCubbins, \& Schwartz, 1984; Rosen, 1989; Wood \& Waterman, 1994), the existence or effectiveness of the accountability-ethics relationship has yet to be systematically examined. A growing body of work on accountability implies that it has a significant impact on administrative behavior (Behn, 2001; Caiden, 1988; Deleon, 1998; Dubnick \& Romzek, 1991, 1993; Kearns, 1996; Romzek, 2000; Romzek \& Dubnick, 1987, 1994, 2000; Romzek \& Ingraham, 2000), but none of these studies directly address how accountability impacts on the ethical standards and strategies adopted by administrators.

The barriers to such an analysis have been conceptual and methodological. Conceptually, both "accountability" and "ethical behavior" have lacked the "sharpness" and clarity (Kaplan, 1964) 
Dubnick ACCOUNTABILITY AND ETHICS: RECONSIDERING THE RELATIONSHIPS 407

required for analytic purposes. The concept of accountability has been characterized as expansive (Mulgan, 2000) and chameleon-like (Sinclair , 1995) as applied in both theory and practice, and the appropriate meaning of ethical behavior has long been the subject of heated debate between utilitarians and deontologists (among others) (Beu \& Buckley, 2001; Garofalo \& Geuras, 1999). The lack of progress in conceptualization, however, can be attributed to the institutional bias and normative ambiguity fostered by our methodological approaches to both terms. Accountability and ethical behavior are rarely perceived in behavioral terms outside the institutional contexts that preoccupy students of public administration. As a result, accountability becomes associated with certain institutional forms of oversight and ethical behavior becomes tangled in discussions of codes and legalisms. As important has been the inability of analysts to put aside the normative "baggage" that accompanies the use of such value-laden terms as "accountable" and "ethical" when describing human behavior (Kaplan, 1964)

We can overcome these barriers by adopting a "middle range" or "concrete theory" perspective (Elster, 1989, 1998; Hedström \& Swedberg, 1998; Lane, 1997) that allows us to reconceptualize both accountability and ethical behavior as "social mechanisms" - that is, in Robert Merton's terms "social processes having designated consequences for designated parts of the social structure"( Merton, 1968). Applying this approach, we assume a sociological (rather than institutional) view of accountability. The sociological view stresses the forms and functions of accountability as processes (mechanisms) that impact on social actors as situated pressures for account-giving behavior. In this essay, we focus on four general types of mechanisms that demand account-giving responses: answerability, blameworthiness, liability and attributability.

Similarly, we regard ethical behaviors as social mechanisms constituted as norms and standards of behavior generated as partial responses to the pressures created by accountability mechanisms. In contrast to both Kantian and utilitarian views of ethics that rely on the existence of a priori knowledge or some universal standard, we assume a more naturalistic (Harman, 1977) and pragmatic perspective that stresses the functional role of ethics in dealing with social dilemmas (LaFollette, 2000; Flanagan, 1996; Putnam, 1998). Our focus is on the development 
and nurturing of ethical behaviors and strategies in response to major forms of sociological accountability.

\section{THE SOCIOLOGICAL PERSPECTIVE}

\section{Three Approaches to Accountability}

Analytically, the concept of accountability can be approached in three ways: historically, institutionally and sociologically. Historic ally, the term itself has distinctly Anglican and feudalistic roots, and has only recently emerged as a universal standard of governance (Dubnick, 1998). Mechanisms similar to the modern concept of accountability, however, do have ancient roots in Athenian democracy (Roberts, 1982; Elster, 1999). More than historical curiosities, both the Anglican and Athenian views of accountability offer insights into modern accountability and provide standards by which to assess the various approaches that emerge from sociological analyses. For present purposes, however, we will focus attention on those views derived from the contemporary study of social relationships.

Institutional perspectives approach accountability as formalized means of feedback and control established with governance structures of states and corporate entities (Schedler, 1999). This view covers a wide range of phenomena, from constitutions to financial reporting standards, and has been the dominant perspective in the study of bureaucratic accountability (Burke, 1986; Gruber, 1987; Rosen, 1989).

Sociological perspectives focus attention on accountability as a type of social act that is part of a larger class of social processes or mechanisms dealing with the need to repair or overcome damaged relationships resulting from "unanticipated or untoward behavior" (Scott \& Lyman, 1968). That group of mechanisms includes confessing to the action or seeking forgiveness (Tavuchis, 1991), subjecting oneself to punishment or retribution (Minow, 1998; Borneman, 1997), engaging in "good works" to make amends for the damage done or seeking the restoration of one's good name (Benoit, 1995), and associated behaviors that stand as substitutes for (or complements of) giving an account of one's behavior. 
Dubnick ACCOUNTABILITY AND ETHICS: RECONSIDERING THE

RELATIONSHIPS

\section{Giving of Accounts}

Specifically, the social "giving of accounts" occurs when one must justify or provide excuses for the action that resulted in the faux pas or untoward act that is the focus of attention (Scott \& Lyman, 1968). One is essentially not denying either active or passive involvement in the particular indiscretion, but is engaging in an effort to explain why one ought not to be held either fully or partly responsible. Justification involves accepting responsibility for the act, but denying the immorality or untowardness of the behavior's consequences. Excuses, in contrast, do not deny the negative consequences of the acts in question, but argues that the account giver had no choice but to act badly and was therefore not responsible (Scott \& Lyman, 1968; Sykes \& Matza, 1957). In this sense, an individual is "accountable" to the extent that there exists an expectation (Cava, West \& Berman, 1995) within the community that they would provide an explanation for any act regarded as worthy of account giving.

While standing as a distinct type among the class of associate mechanisms relating to repairing damaged relationships, account giving may also serve as a necessary complement to the other forms. The expectation to provide a justification or excuse for one's ations may include a demand for an accounting even if the individual confesses to the act, apologizes, and submits to punishment or undertakes restitution. Consider the case of Scott Waddle, commander of the submarine U.S.S. Greeneville that collided with a Japanese vessel, the "Ehime Maru", south of Hawaii on February 9, 2001. The incident, which led to nine deaths, was the subject of a military court of inquiry, and by April Commander Waddle had accepted "full responsibility and accountability" for the accident and made several widely publicized apologies. But in this instance, and others like it, the public admission of guilt and expression of regret and apologies did not preclude the requirement for an accounting of what took place. Thus, with each public appearance, Commander Waddle had to relive the incident and provide an account of why he acted as he did.

In contrast, there are some acts of omission or commission considered so despicable that no amount of excuses or justifications would be acceptable. For example, Adolph Eichmann, Albert Speer, and other Nazis offered defenses of their actions based on accounts that they were just "following orders," carrying out their civic and legal "duties," 
or (in the case of Speer) unaware of what was taking place despite their prominent roles in the German war effort (Arendt, 1976; Sereny, 1995). No account giving in the form of excuses or justifications was perceived as acceptable.

\section{Typology of Account-Giving Mechanisms}

With its focus on actions taken in response to social expectations, the sociological perspective can generate a useful typology of account-giving mechanisms. Expectations relevant to providing an explanation for one's behavior can be viewed along two dimensions. First, the expectations can be related to specific actors or they can focus on situations. Second, the expectations setting or environment can be highly structured and relatively stable or emergent and subject to fluctuation. Figure 1 illustrates the resulting forms of socially relevant accountability emerging from relating these two dimensions.

In the sections that follow, we describe the distinctive features of the resulting four types of account-giving mechanisms and discuss the relevant literature associated with each. As important, we briefly consider the implications of each for generating ethical behavior mechanisms among those being held accountable. As we will see, accountability and ethics are closely related both analytically and empirically.

FIGURE 1

Types of Accountability

\begin{tabular}{|l|l|l|}
\hline $\begin{array}{l}\text { Expectations are: } \\
\text { Related to Persons }\end{array}$ & Structured & Emergent \\
\cline { 2 - 3 } $\begin{array}{l}\text { A. ANSWERABILITY } \\
\text { Events }\end{array}$ & B. BLAMEWORTHINES $\$$ \\
\hline
\end{tabular}

TYPE A: ACCOUNTABILITY-AS-ANSWERABILITY

\section{Demanding Answers}

Role-specific expectations for account giving are those found in highly structured social relationships where the tasks and obligations of individuals are either clearly articulated (i.e., formalized) or so "institutionalized" (in the sense of "regularized") that they are perceived 
Dubnick ACCOUNTABILITY AND ETHICS: RECONSIDERING THE RELATIONSHIPS 411

as inherent to the position a person is occupying (Turner, 1978; Biddle, 1986). We label this form of accountability "answerability" to stress the idea that persons who fall in this category are expected to respond to calls for giving an account upon demand. In short, that expectation comes with their role. This conceptualization of accountability is among the most commonly used, and has been central to contemporary studies of democratic and organizational accountability (Caiden, 1988; Schedler, 1999).

Within democratic theory (Held, 1996; Pitkin, 1969), accountabilityas-answerability indicates a relationship between the governors and the governed involving mechanisms requiring the former to inform the latter of actions taken on their behalf (i.e., in their "interest"), and allowing the latter to judge and take action against the former based on that information. The specific mechanisms involved range from accountability through elections (Fearon, 1999) and mediated procedures (such as a "vote of no confidence" in parliamentary systems) (Laver \& Shepsle, 1999) to the creation and strengthening of "horizontal" institutions such as courts and ombudsman offices (Schedler, Diamond \& Plattner, 1999). Accountability-as-answerability has also played a central role in classic al and contemporary organization theory, where the central problem has been to develop mechanisms (e.g., chain of command, limited span of control) and related strategies for creating and sustaining cooperative social systems (Barnard, 1968; March, 1958; McGregor, 1960).

\section{Answerabilty Research}

There have been several streams of research associated with accountability-as-answerability mechanisms, each applying a distinct model of the social relationship involved and generating a different picture of the ethical implications of answerability. One stream models answerability as a relationship between an accountable individual and the audience to which he or she must provide the account. In a series of articles published in the 1980s, Teltock and his colleagues found that being told one must provide a justification for a decision had a significant influence on the individual's approach to each decision (Tetlock, 1983a, 1983b, 1985; Tetlock \& Kim, 1987). Moreover, individuals put in such situations were motivated to seek the approval of their perceived audiences, leading Tetlock to develop an "accountability 
theory" emphasizing the view of answerable individuals as "intuitive politicians" "whose primary goal is to protect their social identities in the eyes of the key constituencies to whom they feel accountable" (Tetlock, Skitka \& Boettger, 1989).

In contrast, a principalagent theory stream provides a contractual context within which answerability mechanisms and relationships are used to overcome the inherent "moral hazard" and "selection" problems principals face when relying on an agent (Eisenhardt, 1989; Miller, 1992; Moe, 1995; Waterman \& Meier, 1998). Here the answerability mechanisms are regarded as structural responses to dilemmas created by the effort of rational principals attempted to control rational agents, each pursuing their own self-interest.

A third research stream, the "new institutionalism," regards organized behavior as dominated by rules and institutional norms, and would treat answerability as part of that rule-structure (March \& Olsen, $1984,1989,1995)$. The accountable individual is a rule-follower whose actions are governed by what March and Olsen termed, the "logic of appropriateness." Under this logic, accountability-as-answerability is dominated by three questions: What kind of situation is this? Who am I (i.e., what is my identity or role)? And what is the rule I should follow given my identity and the situation? (March, 1994).

\section{Answerability Ethics}

The three perspectives on accountability-as-answerability present us with alternative models of the accountable actor, and thus imply three models of ethical behavior mechanisms. The ethics of Tetlock's intuitive politician are driven by the psychological need to be accepted by the "audience" - in the case of elected officials, the electorate or the people; in the case of a public administrator, the client or supervisor or stakeholder. This can result in an approach that judges the ethicality of actions on the basis of their strategic value (Paul \& Strbiak, 1997). The ethics of the rational self-interested agent is shaped by that individual's calculation of what actions will best suit his or her interests, whether those interests are focused on the accumulation of power, the accumulation of wealth, or some other goal (Bøhren, 1998; Brehm \& Gates, 1997). The rule-follower's ethics is primarily shaped by role expectations and the individual's social identity - a fact that leads him or her to select the most "appropriate" action among alternatives 
Dubnick ACCOUNTABILITY AND ETHICS: RECONSIDERING THE RELATIONSHIPS

based on assessments of what best fits that identity and set of expectations.

What these three ethical roles share in common is a reliance on exogenous signals or structures. The intuitive politician is constantly monitoring his or her audience for signals about appropriate behavior, while the rational agent is engaged in ongoing calculations about that behavior that will provide the best payoff. The rule-follower, in the meantime, is always engaged in balancing the expectations associated with his or her social identity with the demands of the situation. All three look outward as they make their ethical choices, and all three reflect a concern for the consequences of their actions. In that sense, Type A accountability tends to make administrators rely on various forms of ethical mechanisms stressing the consequences of their actions vis-à-vis the expectations of those to whom they are answerable. This stress on consequences will, in turn, lead to the adoption of ethical strategies drawn from teleological schools of ethics (Scheffler, 1994), giving logical support to the various models of bureaucratic behavior applied or implied in many positive, political and organizational theories. Among positive theories of bureaucratic behavior, mechanisms rooted in utilitarian ethics (act, rule and motive) are the assumed position for administrator actions. Similarly, political theories of bureaucratic behavior emphasize mechanisms that enhance the influence and power of agencies, while organization theories focus on the striving for autonomy, security and resources. Implied in all these models is a set of ethical strategies closely linked to Type A accountability.

\section{TYPE B: ACCOUNTABILITY-AS-BLAMEWORTHINESS}

\section{Status -Based Accountability}

While accountability is most often thought of in terms of answerability, it is not always applied to persons in specific and defined roles. Blameworthiness as a form of accountability involves a shift in focus from specific roles and contractual obligations as an agent to one's perceived social status and membership in some group that has status. While role identifies what tasks and functions you perform, status implies power and influence within the organization (Stryker \& Macke, 1978). Put briefly, one is held accountable not because of one's tasks or formal responsibilities, but because of one's relative social position or identification with a certain group. Thus, you are held accountable 
because you are regarded as a socially, if not organizationally, blameworthy (Dubnick, 1996).

In its most extreme form, Type B accountability involves "scapegoating" - that is, imposing blameworthiness on a group simply by characterizing it as the source of the undesirable condition (Douglas, 1995; Girard, 1986). It is, in Peter Gay's words, the construction of a "convenient Other" upon whom one can visit all the blame for any problem - and against whom we can target our anger and aggression (Gay, 1993).

But accountability-as-blameworthiness can take less extreme forms as well. In military organizations, for example, those at the highest echelons of any unit are deemed blameworthy and accountable for events that occur on their "watch." This form of accountability differs from mere answerability, which is related to whether one is performing one's specific role. Here the primary issue is one's status as the commanding officer that is most important.

A relevant case is that of Rear Admiral Husband E. Kimmel, Commander-in-Chief of the Pacific Fleet at the time of the Japanese surprise attack on Pearl Harbor on December 7, 1941. There is no question that the devastation wrought by Japan's forces was causally responsible for the damages suffered on that "day of infamy." Yet both Admiral Kimmel and Lt General Walter Short, who was Commanding General of the local Army contingent, were officially blamed and sanctioned for the state of "unreadiness" at Pearl Harbor on the morning of the infamous attack, and their careers were ended despite their potential value as commanders in the war that followed (Cohen \& Gooch, 1991). Similarly, in a statement issued in July, 1997, then-Secretary of Defense William Cohen held Brigadier General Terryl Schwalier "personally accountable" for the lax force protection that led to the death of 19 American service personnel at the Khobar Towers bombing a year earlier (Cohen, 1997). The facts in both cases indicated that there was more blame to go around than that visited on Kimball, Short or Schwalier, but that is not the way accountability operates in the military. "In the military," observed Judith Shklar, "responsibility has to be personalized at the highest level of the organization since its system of command is built on the principles of obedience and reliance.... We cannot afford to be philosophically discriminating when our security depends on maintaining the principles of hierarchical responsibility for victory and defeat, especially the latter" (Shklar, 1990, p. 63). 
Dubnick ACCOUNTABILITY AND ETHICS: RECONSIDERING THE RELATIONSHIPS

\section{Blameworthiness In Public Service Cultures}

While accountability-as-blameworthiness is an accepted part of military culture (and can be found in some organizations that model themselves after the military, e.g. some police forces), it is rarely evident in other formal organization contexts. However, it is a pervasive presence in the extra-organizational contexts of public service. Our government and its agents operate in a culture where officials are implicitly held blameworthy for all possible misfortunes, regardless of causal responsibility (Dubnick, 1996; Shklar, 1990). A hurricane is an act of nature, but government meteorologists will be held accountable for forecasting its exact point of impact as well as expected intensity, and local emergency preparedness offices will be blamed if proper steps were not taken to deal with the storm's impact. In the aftermath of the September 11, 2001 attacks on the World Trade Center and the Pentagon, issues were raised about the competence and culpability of the U.S. intelligence community as well as security at America's airports. Within two weeks of those tragic events, the media began to castigate the policies of the U.S. Immigration and Naturalization Service for its inability to track aliens who remained in the country illegally. Like other public sector agencies, they were blameworthy; unlike others, they were called into account for their implied role in facilitating the devastating attack.

What is involved in this form of accountability comes close to what is traditionally termed "moral responsibility." As Marion Smiley notes, in both its Christian and Kantian forms, moral responsibility implied the existence of some higher or external authority. Under those forms, blameworthiness was a matter of whether one was in a position to violate the norms of those universal standards that constituted morality. But in discussing accountability-as-blameworthiness, we are focused on the social construction of blameworthiness and the social practice of blaming (Smiley, 1992). We are blameworthy as a result of our status within a community (e.g., the mayor) or organization (e.g., the general), and not due to any specific task responsibilities or actual authority; and we are blameworthy because we are members of a group whose members are regarded as blamable (e.g., bureaucrats, politicians), and not because anyone in that group could really be an effective agent. 


\section{Type B Ethical Responses}

The ethics of those facing Type B accountability is necessarily pragmatic in the broadest sense of that term, and can take three forms beyond the mere passive acceptance of one's fate as a blameworthy actor. First, accountability-as-blameworthiness can be approached instrumentally. Faced with the social reality of blameworthiness, the accountable individual should use the situation to deal with the challenges within that context. The heads of agencies that have been subjected to severe criticism for past performance can use the opportunity to strengthen the organizations capacities for the future. In response to their experiences as field-level soldiers in Vietnam, the officers who rose through the military's ranks from the mid-1970s through the 1980s developed ethical strategies that literally transformed the role of the armed forces in U.S. policy as well as the way the military was perceived by the public and perceived itself (Woodward, 1991; Kitfield, 1995). An equally dramatic transformation of the ethical and operational norms of the Federal Emergency Management Agency took place under James Lee Witt, who assumed his position in April 1993 in the wake of severe criticism for FEMA's handling of recent disaster relief efforts.

A second approach is to assume a commitment to a deontological moral standard (Chandler, 1994) that would meet with widespread approval within the community or organization. The call for public administrators to focus on "service" rather tan "steering" (Denhardt \& Denhardt, 2000), to engage in the pursuit of the "public interest" (Huddleston, 1981-82; Marx, 1949), to adopt a professional standard of social equity (Frederickson, 1997; Marini, 1971), or to "refound" itself in the regime values of the constitution (Wamsley \& Wolf, 1996; Wamsley et al., 1990), are part of this effort to fill the moral void implied by the condition of blameworthiness.

The third approach is to engage in an "identity shift" by dissociating oneself from the blameworthy status or group. Under the view of social constructivism, just as certain groups are regarded as blameworthy, so other groups are inherently praiseworthy. In lieu of a tag such as "bureaucrat" or government employee, one can stress a professional identity such as city planner, park ranger or law enforcement official. These identity shifts, in turn, have implications for the type of accountability and ethical standards one is subject to. Of course, as social constructions, the blameworthiness of these identities can vary from 
Dubnick ACCOUNTABILITY AND ETHICS: RECONSIDERING THE RELATIONSHIPS 417

place to place and overtime. Police officers in a small midwestern town will faces a different set of community expectations than their peers in New York or Los Angeles; similarly, the status and perception of an FBI agent in the 1990s was quite different from that of the 1950s.

Common among these three Type B responses is the establishment of credibility for public administrators as autonomous ethical actors. The post-Vietnam era commanders focused on establishing and articulating basic rules for the use of military force - rules that sometimes led them to openly resist putting U.S. personnel in harm's way when other options were available. The military professionalism represented by the likes of George Patton was replaced by the model provided by Colin Powell and his cohort (Campbell, 1998). The call for the public service professional to give priority to general ethical commitments is also a step toward asserting an ethically autonomous position, as is the effort to create a distinct professional identity among the public service professions. Each of these is a means toward the realization of Carl Friedrich's model of the responsible administrator.

\section{TYPE C: ACCOUNTABILITY-AS-LIABILITY}

\section{Law-Like Situations}

In contrast with accountabilities based on the expectations related to persons, Types $\mathrm{C}$ and $\mathrm{D}$ accountabilities focus on the structure of the situation in which actors operate. Although posited as distinct types, accountability-as-liability and accountability-as-attributability would more appropriately be described as forms found at opposite ends of a continuum. At one end are highly structured contexts in which expectations are well defined and clear to all; at the other extreme are situations so vaguely defined that they almost devoid of stable expectations. Our present focus, Type $\mathrm{C}$ accountability, falls on the "highly structured" section of that range.

As implied in its name, accountability-as-liability is closely associated with a legalist view of the world in which actions are guided and assessed according to rules that carry sanctions for non-compliance (Shklar, 1986). Unlike answerability (Type A), where expectations for accountability derive from the actor's institutional role or organizational position, liability stresses the requirements of the structured situation. The nature of that structure can vary from the strictures of legal 
requirements backed by state sanctions to implicit contracts between two parties that carry with them rewards for compliance and/or sanctions for violations. At the core of all these mechanisms is the idea that law, in a very general sense, is an effective way to establish and maintain order and control (Pound, 1997; Schuck, 1999).

In a strictly formal sense, accountability-as-liability would be limited to shaping one's actions according to the "letter of the law" - that is, doing what is required by law, and avoiding those actions prescribed under law. For Type $\mathrm{C}$ accountability, however, the conception of law is much broader, taking on the characteristics of both an institutional setting (i.e., the "rule of law") (Ingram, 1985; Hayek, 1972) and a context for social relationships (Fuller, Elelman \& Matusik, 2000; Minow, 1990, 1997; Weber, 1978).

\section{Issues of Liability}

The relationships between Type $\mathrm{C}$ and other forms of accountability are quite complex for two related reasons. First, ours is an "organizational society" where individuals are constantly identified by their role or status. It is rare to find a structured situation where one is completely without some role identity. Accountability-as-liability, however, tends to focus the act and its consequences rather than the actor or her status-derived blameworthiness. In its most stringent form, Type C accountability seeks out the actor who "did the deed" (was directly, causally responsible) rather than the individual "in charge" or playing some other relevant role. Thus, an individual in a supervisory role/status would not be held accountable unless there was both evidence and willingness to link that person to the untoward activity.

For example, in the case of the infamous 1969 My Lai massacre, the U.S. Army felt that it had to treat the event as a legal case, and in so doing it found its ability to hold people accountable severely limited. Taking the legal liability route, the Army charged Lieutenant William Calley with the premeditated murder of at least four civilians. Several others in command positions at the scene of the massacre (which involved at least 175 to 200 deaths) were initially charged, but it was later decided to drop those charges in all but one additional case due to "insufficient evidence" - a standard reflecting the legal nature of the accountability approach being applied. The exception was Captain Ernest Medina, Calley's immediate superior officer, who was also brought to trial charged with murder. There was a difference, however. The murder 
Dubnick ACCOUNTABILITY AND ETHICS: RECONSIDERING THE RELATIONSHIPS 419

charges against him were not for specific acts of premeditated killing (although evidence indicates that he killed at least four civilians at My Lai); rather, he was charged with 102 murders under a provision of military law that allowed prosecution of those with command responsibility. He was court-martialed and acquitted of those charges. Thus, although the military could have (and did in many cases) hold many more persons blameworthy under its Type B accountability approach (and subject to organizational sanctions), it held only Calley legally liable for four of approximately 200 deaths and sentenced him to twenty years in prison. By focusing on liability, in other words, and not pursuing specific counts of premeditated murder again Medina and others, the military was unable to fulfill the need for accountability-asliability.

This leads to the second issue associated with Type $\mathrm{C}$ accountability: the problem of collective responsibility (French, 1997). Just as the legal system has difficult dealing with collective responsibility (Stone, 1975), liability-based accountability systems are constantly challenged by the "many hands" problem (Thompson, 1980). As Dennis Thompson notes, typical solutions to this problem include applying "hierarchical" or "collective" forms of responsibility, and he finds both wanting. In their place, he advocates applying "personal responsibility" approach based on some weak causal connection between an individual and the event. In terms of the present framework, that would mean shifting from Type $\mathrm{C}$ to either Type A or Type B accountability - a move that raises issues regarding the integrity and fairness of any sanctions that might be imposed. As important, such an approach does not deal with the complex situations where even a weak causal link cannot be proven. In such cases, even the legal system has had to modify its standards by allowing liability to rest almost entirely on an individual possible "fault" rather than cause (Thomson, 1984).

As with its legal equivalent, the inherent problems of accountabilityas-liability are many (Howard, 1994b; Huber, 1988; Levmore, 1994; Lieberman, 1981). Nevertheless, it is an approach to accountability that is extremely important in public administration. A central factor shaping Type $\mathrm{C}$ accountability for public administrators has been the judicial treatment of two issues: administrative discretion and administrative immunity. Historical shifts in the judiciary's handling of administrative discretion and delegation of authority cases (Horwitz, 1994; Stewart, 
1975) have altered the jurisdictions and tasks of administrative agencies to such a degree (some have argued) that we have witnessed a de facto constitutional transformation of the American republic (Lowi, 1979). The courts' willingness to lift the cover of sovereign immunity over the past several decades (Rosenbloom, 1983, 1987) has been as significant in its impact on the accountability, exposing administrators to legal actions and making it urgent for them to become more "constitutionally competent" (Rosenbloom, Carroll \& Carroll, 2000).

But as significant has been the general impact on public administration of the legalistic mindset fostered by these developments. Almost every area of public management has shown signs of deference to the "lawyers" perspective, and an abandonment of the administrator's view of the world (Dimock, 1980). The very act of entering the public service places one in a distinctive legal relationship to the state (Rosenbloom, 1971), and efforts to assure public employee integrity through Type $\mathrm{C}$ approaches have been pervasive and often counterproductive for the day-to-day operations of government (Anechiarico \& Jacobs, 1996).

\section{Law-Like Ethics}

The ethics related to Type $\mathrm{C}$ accountability have their roots in distinct and conflicting conceptions of law. Two approaches emerge from debates among philosophers regarding the nature of law, while a third is derived from the analogical reasoning used in the practice of law.

In the philosophy of law, a major division exists between those who assume laws to be human artifacts without any inherent moral value (the positivist school) and those who assess laws in terms of their relation to a higher law standard (the natural law school). Each of these schools generates a number of ethical positions, but for present purposes we will offer them in caricature as the positivist ethics of obligation and the naturalist ethics of conscience. As applied by those who are held accountable, the ethics of obligation calls for adherence to the explicit rules that define a situation. Here we find the ethics of neutral competence that has been so central to the norms of American public administration (Kaufman, 1956; Lockard, 1962; Finer, 1936; Rourke, 1992). The ethics of conscience, in contrast, is manifest in efforts to have public administrators adhere to some "higher standard" when engaged in the enforcement or implementation of the law. Here, again, we find various standards from "regime values" and "public interest" to 
Dubnick ACCOUNTABILITY AND ETHICS: RECONSIDERING THE RELATIONSHIPS 421

"social equity" and "justice-as-fairness" (Frederickson, 1997; Marshall \& Choudhury, 1997; Rohr, 1989, 1998).

A third ethical pproach relevant to Type $\mathrm{C}$ accountability comes from the practice of law. Sunstein (Sunstein, 1996) offers the term "analogical reasoning" to describe the type of thinking that takes place in legal practice. It is reasoning that focuses on applying laws and rules to specific cases based on how that law or rule has been applied in the past to similar (although not identical) cases. Sunstein highlights four features of analogical reasoning. First, it is based on the norm of "principled consistency" - that is, the need to provide some principle to "harmonize seemingly disparate outcomes." Second, there should be a focus on the details of the case, letting the facts shape the decision. Third, analogical reasoning avoids the application of any "deep or comprehensive theory" that might overwhelm the facts of the case. Finally, this form of reasoning produces and applies standards that should be at a "low or intermediate level of abstraction." In public administration, the ethics of "constitutional competence" advocated by Rosenbloom and Carroll (Rosenbloom, 1987; Rosenbloom, Carroll \& Carroll, 2000) operates at this analogical level by focusing on the need for public service employees to become familiar with their place and responsibilities within the U.S. constitutional system through relevant cases.

The common thread holding these Type $\mathrm{C}$ ethical strategies together is their commitment to determining what is ethical through a reasoning process - one guided by rules, the second by a higher standard, and the third through analogy. In contrast to the stress on consequences (generated by Type A account giving) and blame avoidance (through Type B), the ethical approaches of Type $\mathrm{C}$ accountability rely on ethical behavior mechanisms that call for an actor to engage in a certain type of reasoning that fosters consideration of procedural requirements, legal standards or precedent (Raz, 1990).

\section{TYPE D: ACCOUNTABILITY-AS-ATTRIBUTABILITY}

\section{Relevance of Nonwork Expectations}

Accountability-as-attributability brings into consideration those arenas of social life where the rules and roles of public administration are seemingly irrelevant, but in fact are potentially quite important in the environment of accountability of public sector workers. It involves those 
contexts where the fact that an individual holds a certain position in an organization, or that one is subject to rules and constraints in the workplace, is of little or no consequence most of the time. It is the context of the "nonwork domain" where one lives a "private life" distinct from the public life of the government job. Or so it seems. In fact, accountability pressures spillover into the private lives of all employees public and private.

In the nonwork domain, one is subject to accountability standards that are broader in scope, more diverse, and constantly subject to change over time and from place to place. The sources of those standards are other social actors in the domain who regard an action or behavior as requiring an accounting by some actor. In short, they attribute an action or behavior to an individual and would expect an accounting if they were in a position to demand one. This attributing behavior is regarded by social psychologists as part of our standards means for making sense of and dealing with - the world (Forsyth, 1980; Crittenden, 1983; Howard, 1994a). From the perspective of "attribution theory" research, this form of attribution is subject to ideological, cultural and stereotypical bias (Howard \& Pike, 1986; Al-Zahrani \& Kaplowitz, 1993) as well as situational determinism (Holloway \& Fuller, 1983). In addition, attributions tend to be unstable and malleable by changing conditions such as information or expectations (Tetlock, 1985; Yarkin-Levin, 1983; Tetlock, 1981). The shortcomings of such attributions, however, have not diminished their relevance.

\section{Being of "Suspect" Character}

The link between specific instances of attribution and our Type D accountability emerges when those attributions lead to the perception of an individual as someone of suspect character given the actions attributed to him or her. Thus, an individual seen emerging in a disheveled state daily from a local bar might be regarded as a "drunk," and someone cited by police for speeding might be characterized as a reckless driver. An attributed behavior becomes a character attribute, and it is the fact that we are subject to such characterizations that can make us Type D accountable. An individual whose actions in private life are found to be questionable or potentially embarrassing to his employer is likely to find him or herself being held accountable for those actions - despite their irrelevance to the employee's tasks or functions. 
Dubnick ACCOUNTABILITY AND ETHICS: RECONSIDERING THE RELATIONSHIPS

This is especially true for those who hold public office. In the private sector, the relevance of Type D accountability pressures is likely to depend on a number of factors, including (but not limited to) one's position and status in the organization and the nature of the nonwork behavior that triggers the concern. Is the individual a highly visible employee whose offense impacts on the public image of the business? Was the behavior so offensive that the presence of the individual will result in significant losses in sales or productivity unless something is done?

Exposure to this form of accountability is unavoidable, and yet students of management have paid little attention to it (Cozzetto \& Pedeliski, 1996, 1997). Scholars have long acknowledged the intermingling of social and personal factors. They were central to the work of the human relations school, and played an important role in Barnard's classic analysis of executive management (Barnard, 1968; Roethlisberger, 1941). Interest in the relationship of family life to work has produced a stream of research in sociology and organization studies (Cohen, 1995; Bielby, 1992) including the examination of strategies developed to deal with the boundaries between work and nonwork (Kirchmeyer, 1977/1993, 1995). There is also research focused on the nonwork lives of public sector workers in particular (Romzek, 1989; Johnson \& Duerst-Lahti, 1991; Romzek, 1985). But, with few exceptions (Dworkin, 1997), little of this research considers the link between personal life and accountability.

\section{Uniqueness of Public Office Holding}

The rules that protect one's private life from public intrusions do not necessarily apply to those in public offices. While modern society might proffer the "principle of uniform privacy" as a desirable standard for all its citizens, for public office holders it is the "principle of diminished privacy" that is more likely to be applied. There are a variety of reasons for this, including the perceived necessity to know more about the behavior of those who wield power over us as well as expectations that

public officials must achieve a higher standard of conduct in their private affairs than ordinary citizens (Thompson, 1987).

Of course, accountability-as-attributability is not limited to those who hold public office. What kind of accountability is involved? Some of it takes the form of formal constraints on the private, nonwork lives of 
government employees. Hatch Acts, conflict of interest legislation and related policies are designed explicitly to deal with the perceived dangers of having civil servants too actively engaged in politics or private business enterprises (Rosenbloom, 1971; Thruber, 1993; Roberts, 1992; Rosenbloom, 1988). Other examples are found in managerial strategies to offset the potentially adverse impact of private preferences. The possibility that employees or their families might grow too attached to local communities ("going native") has led some agencies to establish personnel transfer policies to minimize the influence of nonwork factors (Kaufman, 1967). Concern for an agency's reputation or public image is also used as a rationale for holding employees accountable for their private behavior and lifestyles. Private behavior has been regarded as grounds for adverse personnel actions, even if the behavior had little or nothing to do with the position of workplace (Lewis, 1997). As significant, the courts have held that the "perception" of questionable private behavior can be used to take action against a public employee (see Wild v. U.S., 1982) (Stark, 1995).

\section{Type D Ethical Strategies}

The ethical responses to Type D accountability pressures are likely to require that the individual accept the linkages between one's personal and professional/work lives. Two assumptions are at work here. First is the assumption that individuals accepting a public office does so with the expectation that they will be subject to diminished privacy and greater scrutiny of their behavior. Second is the fact that in today's complex social world, efforts to carve out a private space free from the intrusions of work or public life is all but impossible. At least some aspects of the behavior attributed to the individual in his or her personal life are relevant to how that individual will be viewed in his or her working life and vice versa. This fact of modern social life means that the ethical demands of work life often overlap or intrude into the ethics of personal life, a phenomenon that has been at the center of many of the most popular and influential studies of American social dynamics over the past half century (Bellah et al., 1985, 1991; Whyte, 1956; Coleman, 1982). The result is the blurring of the lines between one's personal and work life ethics.

Thus, the individual must constantly contend with an existential conflict between ethical demands generated by one's role expectations, perceived blameworthiness or liability, and those related to one's 
Dubnick ACCOUNTABILITY AND ETHICS: RECONSIDERING THE RELATIONSHIPS

standing as an autonomous private individual or citizen. In some cases, the solution would be an ethical position that subordinates at least some of one's personal autonomy to the demands emerging from Types A, B or C accountability. Accepting the limits on one's citizenship rights is the price paid under certain Hatch Act provisions, just as the Forest Ranger accepts the order to move her family to the next assignment station. As significant is the choice to subordinate one's private tastes and behavior to the demands imposed by one's job or status (Hummel, 1994; Denhardt, 1981).

A more positive stance has been articulated by Terry Cooper in his calls for a "citizenship ethics" that he hter presents as the "responsible administrator" model (Cooper, 1991, 1998). Subordination of the personal is replaced with a commitment to continuously reflect on one's life as a public administrator. Implied is the idea that one can achieve self-actualization through such an ethical stance, an idea that traces back to ancient ethics and its emphasis on ethics as a means for achieving the good (e.g., happiness) in oneself (in contrast to the modern focus on achieving the good for others) (Annas, 1992).

At a more general level, the response to Type D accountability might be the adoption of a virtue or character ethics approach. In an environment where standards and rules are ambiguous or unstable, it would be reasonable to assume that a consistent adherence to some higher standards of personal conduct (e.g., to be trustworthy, honest, benevolent, caring) would provide some protection from the whims of accountability-as-attribution. Some have articulated this in terms of being a person of "good character" (Luke, 1994). It can also involve a commitment to act virtuously on and off the job as the situation requires (Frederickson \& Hart, 1985, 1997; Hart, 1984, 1994; Hart \& Smith, 1988), or at least to avoid falling prey to the "ordinary vices" that plagued us in both our private and public existence (Shklar, 1984).

The ethical path selected in response to Type D accountability pressures has implications for the general orientation of the individual toward the other forms of accountability. Deference to the intrusions of accountability-as-attributability is most closely associated with the norm of political neutrality that has characterized mainstream public administration for many decades. A "citizenship ethics" is likely to complement the effort to promote competency-centered ethics, while implied in the virtue/character ethics approaches is a view of the public 
administrator as a more actively engaged autonomous ethical agent who understands his or her moral obligations (Bowens, 1998).

\section{SUMMARY AND IMPLICATIONS}

Among the various issues raised by the Friedrich-Finer debate, those focused on accountability-ethics relationships are at once the most significant and least explored. Despite the lack of explicit attention to that relationship in the public administration literature, there are obviously considerable resources that can be brought to bear on this topic. Through the reconceptualization of the key terms in that relationship, this essay opens the door to a more thorough examination of the relevant issues.

Such an examination would begin with a further elaboration and empirical validation of the associations summarized in Figure 2. If those posited relationships are validated, the implications for our understanding of administrative behavior can be significant. By focusing on accountability and ethical norms and standards as social mechanisms, we can start to re-explore the "black box" of "contingent" administrative behavior that has been so central to public administration scholarship since Herbert Simon began to model the administrative decision maker in the 1940s. Relying on social mechanisms in lieu of models and positive theory assumptions about bureaucratic behavior, we are able to consider various forms of reasoning and "reasons" that help shape administrative choices and behavior (Elster, 1989; Hedström \& Swedberg, 1998).

There are also potential implications for those concerned with institutional design and administrative reform. Reformers who advocate

FIGURE 2

Accountability-Ethics Relationships

\begin{tabular}{|l|l|l|l|}
\hline Accountability Type & \multicolumn{3}{|c|}{ Ethical strategies based on: } \\
\hline A. Answerability & $\begin{array}{l}\text { Intuitive } \\
\text { politician }\end{array}$ & Rational agent & Rule-follower \\
\hline B. Blameworthiness & Instrumental & $\begin{array}{l}\text { Higher moral } \\
\text { standard }\end{array}$ & Identity shift \\
\hline C. Liability & $\begin{array}{l}\text { Positivist } \\
\text { obligation }\end{array}$ & $\begin{array}{l}\text { Naturalist } \\
\text { conscience }\end{array}$ & $\begin{array}{l}\text { Analogical reasoning } \\
\text { competence }\end{array}$ \\
\hline D. Attributability & Subordination & $\begin{array}{l}\text { Citizenship } \\
\text { ethics }\end{array}$ & $\begin{array}{l}\text { Virtue/character } \\
\text { ethics }\end{array}$ \\
\hline
\end{tabular}


Dubnick ACCOUNTABILITY AND ETHICS: RECONSIDERING THE RELATIONSHIPS 427

greater accountability, for instance, typically put forward suggestions that create or enhance answerability mechanisms. A more fully elaborated "theory" of the relationship between accountability and ethical strategies would help us assess the potential impact of alternative forms of answerability as well as explain the success or failure of various reforms. The same logic could be useful in highlighting the source of current problems. What might otherwise be perceived as an arbitrary abuse of discretionary authority, for example, might be back to the absence of (or an indifference to) Type $\mathrm{C}$ accountability mechanisms.

\section{REFERENCES}

Aberbach, J. D. (1990). Keeping a watchful eye: The politics of congressional oversight. Washington, DC: The Brookings Institution.

Al-Zahrani, S. S. A., \& Kaplowitz, S. A. (1993). Attributional biases in individualistic and collectivistic cultures: A comparison of Americans with Saudis. Social Psychology Quarterly, 56 (3), 223233.

Anechiarico, F., \& Jacobs, J. B. (1996). The pursuit of absolute integrity: how corruption control makes government ineffective. Chicago, IL: University of Chicago Press.

Annas, J. (1992). Ancient ethics and modern morality. Philosophical Perspectives, 6, 119-136.

Appleby, P. H. (1952). Morality and administration in democratic government. Baton Rouge, LA: Louisiana University Press.

Arendt, H. (1976). Eichmann in Jerusalem: A report on the banality of evil (revised ed.). New York: Penguin Books.

Balla, S. J. (1998, September). Administrative procedures and political control of the bureaucracy. American Political Science Review, 92 (3), 363-373.

Barnard, C. I. (1968). The functions of the executive. Cambridge, MA: Harvard University Press.

Bellah, R. N., Madsen, R., Sullivan, W.M., Swidler, A., \& Tipton, S.M. (1985). Habits of the heart: Individualism and commitment in American life. Berkeley, CA: University of California Press. 
Bellah, R. N., Madsen, R., Sullivan, W. M., Swidler, A., \& Tipton, S. M. (1991). The good society. New York: Alfred A. Knopf.

Behn, R. D. (2001). Rethinking democratic accountability. Washington, DC: Brookings Institution Press.

Benoit, W. L. (1995). Accounts, excuses, and apologies: A theory of image restoration strategies. Albany, NY: State University of New York Press.

Beu, D., \& Buckley, M. R. (2001). The hypothesized relationship between accountability and ethical behavior. Journal of Business Ethics, 34(2), 57-73.

Biddle, B. J. (1986). Recent development in role theory. Annual Review of Sociology, 12, 67-92.

Bielby, D. D. (1992). Commitment to work and family. Annual Review Of Sociology, 18, 281-302.

Bøhren, Ø. (1998). The agent's ethics in the principalagent model. Journal Of Business Ethics, 17, 745-755.

Borneman, J. (1997). Settling accounts: Violence, justice, and accountability in postsocialist Europe. Princeton, NJ: Princeton University Press.

Bovens, M. (1998). The quest for responsibility: Accountability and citizenship in complex organisations. Cambridge, UK \& New York: Cambridge University Press.

Brehm, J., \& Gates, S. (1997). Working, shirking, and sabotage: bureaucratic response to a democratic public. Ann Arbor, MI: University of Michigan Press.

Burke, J. P. (1986). Bureaucratic responsibility. Baltimore, MD: Johns Hopkins University Press.

Caiden, G. E. (1988). The problem of ensuring the public accountability of public officials. In Jabbra, J. G. \& Dwivedi, O. P. (Eds.). Public service accountability: A comparative perspective (pp. 17-38). West Hartford, CT: Kumarian Press.

Calvert, R. L., McCubbins, M. D., \& Weingast, B. R. (1989). A theory of political control and agency discretion. American Journal of Political Science, 33 (3), 588-611. 
Dubnick ACCOUNTABILITY AND ETHICS: RECONSIDERING THE

RELATIONSHIPS 429

Campbell, K. J. (1998). Once burned, twice cautious: Explaining the weinberger-powell doctrine. Armed Forces And Society, 34 (3), 357374.

Cava, A., West, J., \& Berman, E. (1995). Ethical decision-making in business and government: An analysis of formal and informal strategies. Spectrum, 68 (2), 28-36.

Chandler, R. C. (1994). Deontological dimensions of administrative ethics. In Cooper, T. L. (Ed.). Handbook of administrative ethics (pp. 147-156). New York: Marcel Dekker.

Cohen, A. (1995). An examination of the relationships between work commitment and nonwork domains. Human Relations, 48 (3), 239263.

Cohen, W. S. (1997, July 31). Personal accountability for force protection at Khobar Towers. Washington, DC: Department of Defense, Office of the Secretary of Defense. [On-line]. Available: www.defenselink.mil/ pubs/khobar/index.html.

Cohen, E. A., \& Gooch, J. (1991). Military misfortunes: The anatomy of failure in war. New York: Vintage Books.

Coleman, J. S. (1982). The asymmetric society. Syracuse, NY: Syracuse University Press.

Cooper, T. L. (1991). An Ethic of citizenship for public administration. Englewood Cliffs, NJ: Prentice Hall.

Cooper, T. L. (1998). The Responsible administrator: An approach to ethics for the administrative role ( $4^{\text {th }}$ ed.). San Francisco, CA: Jossey-Bass Publishers.

Cozzetto, D. A., \& Pedeliski, T. B. (1996). Privacy and the workplace. Review of Public Personnel Administration, 16 (2), 21-31.

Cozzetto, D. A., \& Pedeliski, T. B. (1997). Privacy and the workplace: Technology and public employment. Public Personnel Management, 26 (4), 515-527.

Crittenden, K. S. (1983). Sociological aspects of attribution. Annual Review of Sociology, 9, 425-446. 
Deleon, L. (1998, Autumn). Accountability in a 'reinvented' government. Public Administration, 76 (3), 539-558.

Denhardt, R. B. (1981). In the shadow of organization. Lawrence, KS: The Regents Press of Kansas.

Denhardt, R. B., \& Denhardt, J. V. (2000). The new public service: Serving rather than steering. Public Administration Review, 60 (6), 549-559.

Dimock, M. E. (1980). Law and dynamic administration. New York: Praeger Publishers.

Douglas, T. (1995). Scapegoats: Transferring Blame. London, UK: Routledge.

Dubnick, M. J. (1996). Public service ethics and the cultures of blame. Paper presented at the Fifth International Conference of Ethics in the Public Service, Brisbane, Australia, August 5-9. Available at: http://www.andromeda.rutgers.edu/ dubnick/papers/blame.pdf.

Dubnick, M. (1998). Clarifying accountability: An ethical theory framework. In Sampford, C. N. P. with Bois, C-A. (Eds.). Public sector ethics: Finding and implementing values (pp. 68-81). Leichhardt, NSW, Australia: The Federation Press/Routledge.

Dubnick, M. J., \& Romzek, B. S. (1991). American public administration: Politics and the management of expectations. New York: Macmillan.

Dubnick, M. J., \& Romzek, B. S. (1993). Accountability and the centrality of expectations in American public administration. In Perry, J. L. (Ed.). Research in public administration (pp. 37-78). Greenwich, CT: JAI Press.

Dworkin, T. M. (1997). It's my life--leave me alone: Off-the-job employee associational privacy rights. American Business Law Journal, 35 (1), 47-103.

Eisenhardt, K. M. (1989). Agency theory: An assessment and review. Academy of Management Review, 14 (1), 57-74.

Elster, J. (1989). Nuts and bolts for the social sciences. New York: Cambridge University Press. 
Dubnick ACCOUNTABILITY AND ETHICS: RECONSIDERING THE RELATIONSHIPS 431

Elster, J. (1998). A plea for mechanisms. In Hedström, P., \& Swedberg, R. (Eds.). Social mechanisms: An analytical approach to social theory (pp. 45-73). Cambridge, NY: Cambridge University Press.

Elster, J. (1999). Accountability in Athenian politics. In Przeworski, A., Stokes, S.C., \& Manin, B. (Eds.). Democracy, accountability, and representation (pp. 253-278). Cambridge, UK \& NY: Cambridge University Press.

Fearon, J. D. (1999). Electoral accountability and the control of politicians: Selecting good types versus sanctioning poor performance. In Przeworski, A., Stokes, S. C., \& Manin, B. (Eds.). Democracy, accountability, and representation (pp. 55-97). Cambridge, UK \& New York: Cambridge University Press.

Finer, H. (1941, Summer). Administrative responsibility in democratic government. Public Administration Review, 1(4), 335-350.

Flanagan, O. (1996). Ethics naturalized: Ethics as human ecology. In May, L., Friedman, M., \& Clark, A. (Eds.). Mind and morals: Essays on cognitive science and ethics (pp. 19-43). Cambridge, MA: MIT Press.

Forsyth, D. R. (1980). The functions of attributions. Social Psychology Quarterly, 43(2), 184-189.

Friedrich, C. J. (1940). Public policy and the nature of administrative responsibility. In Friedrich, C. J., \& Mason, E. S. (Eds.). Public policy: A yearbook of the graduate school of public administration (pp. 3-24). Cambridge, MA: Harvard University Press.

Frederickson, H. G. (1997). The spirit of public administration. San Francisco, CA: Jossey-Bass Publishers.

Frederickson, H. G., \& Hart, D. K. (1985). The public service and the patriotism of benevolence. Public Administration Review, 45 (5), 547-553.

Frederickson, H. G., \& Hart, D. K. (1997). Patriotism, benevolence, and public administration. In Frederickson, H. G. (Ed.) The Spirit of Public Administration (pp. 195-208). San Francisco, CA: JosseyBass Publishers. 
French, P. A. (Ed.) (1997). Individual and collective responsibility (2nd. ed.). Rochester, VT: Schenkman Books.

Fuller, S. R., Edelman, L. B., \& Matusik, S. F. (2000). Legal readings: Employee interpretation and mobilization of law. Academy $O f$ Management Review, 25 (1), 200-216.

Gay, P. (1993). The Cultivation of hatred: The bourgeois experience, Victoria to Freud. New York: W. W. Norton and Co.

Garofalo, C., \& Geuras, D. (1999). Ethics in the public service: The moral mind at work. Washington, DC: Georgetown University Press.

Gilbert, C. E. (1959, August). The framework of administrative responsibility. Journal of Politics, 21 (3), 373-407.

Girard, R. (1986). The scapegoat. Baltimore, MD: Johns Hopkins University Press.

Gruber, J. E. (1987). Controlling bureaucracies: Dilemmas in democratic governance. Berkeley, CA: University of California Press.

Harman, G. (1977). The nature of morality: An introduction to ethics. New York: Oxford University Press.

Harmon, M. M. (1995). Responsibility as paradox: A critique of rational discourse on government. Thousand Oaks, CA: Sage publications.

Harris, J. P. (1964). Congressional control of administration. Washington DC: Brookings Institution.

Hart, D. K. (1984, March). The virtuous citizen, the honorable bureaucrat, and 'public' administration. Public Administration Review, 44 (Special Issue), 111-120.

Hart, D. K. (1994). Administration and the ethics of virtue: In all things, choose first for good character and then for technical expertise. In Cooper, T. L. (Ed.). Handbook of Administrative Ethics (pp. 107123). New York: Marcel Dekker.

Hart, D. K., \& Smith, P. A. (1988). Fame, fame-worthiness, and the public service. Administration \& Society, 20(2): 131-151.

Hayek, F. A. V. (1972). The constitution of liberty. Chicago, IL: Regnery. 
Dubnick ACCOUNTABILITY AND ETHICS: RECONSIDERING THE

RELATIONSHIPS 433

Hedström, P., \& Swedberg, R. (1998). Social mechanisms: An introductory essay. In Hedström, P., \& Swedberg, R. (Eds.). Social mechanisms: An analytical approach to social theory (pp. 1-31). Cambridge, UK \& NY: Cambridge University Press.

Hedström, P.; Swedberg, R. (Eds.) (1998). Social mechanisms: An analytical approach to social theory. Cambridge, UK \& New York: Cambridge University Press.

Held, D. (1996). Models of democracy ( $2^{\text {nd }}$ ed.). Stanford, CA: Stanford University Press.

Holloway, S. D., \& Fuller, B. (1983). Situational determinants of causal attributions: The case of working mothers. Social Psychology Quarterly, 46 (2), 131-140.

Hood, C., James, O., \& Scott, C. (2000). Regulation of government: Has it increased, is it increasing, should it be diminished? Public Administration, 78 (2), 283-304.

Horwitz, R. (1994). Judicial review of regulatory decisions: The changing criteria. Political Science Quarterly, 109 (1), 133-169.

Howard, J. A. (1994a). A social cognitive conception of social structure. Social Psychology Quarterly, 57 (3), 210-227.

Howard, J. A., \& Pike, K. C. (1986). Ideological investment in cognitive processing: The influence of social statuses on attribution. Social Psychology Quarterly, 49 (2), 154-167.

Howard, P. K. (1994b). The death of common sense: How law is suffocating America. New York: Random House.

Huber, P. W. (1988). Liability: The legal revolution and its consequences. New York: Basic Books.

Huddleston, M. W. (1981-82). The carter civil service reforms: Some implications for political theory and public administration. Political Science Quarterly, 96 (4), 607-621.

Hummel, R. P. (1994). The bureaucratic experience: A critique of life in the modern organization ( $4^{\text {th }}$ ed.). New York: St. Martin's Press.

Ingram, P. (1985). Maintaining the rule of law. Philosophical Quarterly, 35 (141), 359-381. 
Johnson, C. M, \& Duerst-Lahti, G. (1991). Private lives and public work: Professional careers in state civil service. Review of Public Personnel Administration, 12 (1), 14-32.

Kanter, R. M. (1977/1993). Men and women of the corporation. New York: Basic Books.

Kaplan, A. (1964). The conduct of inquiry: Methodology for behavioral science. Scranton, PA: Chandler Publishing Co.

Kaufman, H. (1956). Emerging conflicts in the doctrines of public administration. American Political Science Review, 50 (4), 10571073.

Kaufman, H. (1967). The forest ranger: A study in administrative behavior. Baltimore, MD: Johns Hopkins University Press.

Kearns, K. P. (1996). Managing for accountability: Preserving the public trust in public and nonprofit organizations. San Francisco, CA: Jossey-Bass.

Kettl, D. F. (1992). Micromanagement: congressional control and bureaucratic risk. In Ingraham, P.W., \& Kettl, D.F. (Eds.). Agenda for excellence: Public service in America (Chapter 5). Chatham NJ: Chatham House.

Kirchmeyer, C. (1995). Managing the work/nonwork boundary: An assessment of organizational responses. Human Relations, 48(5), 515-536.

Kitfield, J. (1995). Prodigal soldiers: How the generation of officers born of Vietnam revolutionized the American style of war. Washington, DC: Brassey's.

LaFollette, H. (2000). Pragmatic ethics. In LaFollette, H. (Ed.). The Blackwell guide to ethical theory (pp. 400-419). Oxford, UK: Malden, MA: Blackwell.

Lane, R. (1997). Political science in theory and practice: The 'politics' model. Armonk, NY: M.E. Sharpe.

Laver, M., \& Shepsle, K. A. (1999). Government accountability. In Przeworski, A., Stokes, S.C. \& Manin, B. (Eds.). Parliamentary democracy, democracy, accountability, and representation (pp. 279296). Cambridge, UK \& New York: Cambridge University Press. 
Dubnick ACCOUNTABILITY AND ETHICS: RECONSIDERING THE RELATIONSHIPS 435

Levmore, S. X. (Ed.) 1994. Foundations of tort law. New York: Oxford University Press.

Lieberman, J. K. (1981). The litigious society. New York: Basic Books.

Lewis, G. B. (1997). Lifting the ban on gays in the civil service: Federal policy toward gay and lesbian employees since the cold war. Public Administration Review, 57 (5), 387-395.

Light, P. C. (1993). Monitoring government: Inspectors General and the search for accountability. Washington, DC: Brookings Institution.

Lockard, D. (1962). The city manager, administrative theory and political power. Political Science Quarterly, 77 (2), 224-236.

Lowi, T. J. (1979). The End of liberalism: The second Republic of the United States (2nd ed.). New York: W. W. Norton and Co.

Luke, J. S. (1994). Character and conduct in the public service: A review of historical perspectives and a definition for the twenty-first century. In Cooper, T. L. (Ed.). Handbook of administrative ethics (pp. 391412). New York: Marcel Dekker.

Marshall, G. S., \& Choudhury, E. (1997). Public administration and the public interest: Re-presenting a lost concept. American Behavioral Scientist, 41 (1), 119-131.

March, J. G. (1994). A primer on decision making: How decisions happen. New York: Free Press.

March, J. G., \& Olsen, J. P. (1984). The new institutionalism: organizational factors in political life. American Political Science Review, 78 (3), 734-749.

March, J. G., \& Olsen, J. P. (1989). Rediscovering institutions: The organizational basis of politics. New York: Free Press.

March, J.G., \& Olsen, J.P. (1995). Democratic governance. New York: Free Press.

March, J. G., \& Simon, H. A. (1958). Organizations. New York: John Wiley and Sons.

Marini, F. (Ed.) (1971). Toward a new public administration: The Minnowbrook perspective. Scranton, PA: Chandler Publishing. 
Marx, F. M. (1949). Administrative ethics and the rule of law. American Political Science Review, 43 (6), 1119-1144.

McCubbins, M. D., \& Schwartz, T. (1984). Congressional oversight overlooked: Police patrols versus fire alarms. American Journal of Political Science, 28 (1), 165-179.

McGregor, D. (1960). The human side of enterprise. New York: McGraw-Hill.

McMahon, C. (1994). Authority and democracy: A general theory of government and management. Princeton, NJ: Princeton University Press.

McSwite, O. C. (1997). Legitimacy in public administration: A discourse analysis. Thousand Oaks, CA: Sage Publications.

Merton, R. K. (1968). Social theory and social structure (enlarged). New York: Free Press.

Miller, G. J. (1992). Managerial dilemmas: The political economy of hierarchy. Cambridge, UK: Cambridge University Press.

Minow, M. (1997). Not only for myself: Identity, politics and the law. New York: The New Press.

Minow, M. (1998). Between vengeance and forgiveness: Facing history after genocide and mass violence. Boston, MA: Beacon Press.

Minow, M. (1990). Making all the difference: Inclusion, exclusion, and American law. Ithaca, NY: Cornell University Press.

Moe, T. M. (1995). The politics of structural choice: Toward a theory of public bureaucracy. In Williamson, O. E. (Ed.). Organization theory: From Chester Barnard to the present and beyond (Expanded, pp. 116-153). New York: Oxford University Press.

Mulgan, R. (2000). 'Accountability': An ever-expanding concept? Public Administration, 78 (3), 555-573.

Paul, J., \& Strbiak, C.A. (1997). The ethics of strategic ambiguity. Journal of Business Communication, 34 (2), 149-159.

Pitkin, H. F. (Ed.) (1969). Representation. New York: Atherton Press.

Pound, R. (1997). Social control through law. New Brunswick, NJ: Transaction Publishers. 
Dubnick ACCOUNTABILITY AND ETHICS: RECONSIDERING THE

RELATIONSHIPS 437

Putnam, R. A. (1998). The moral impulse. In Dickstein, M. (Ed.). The Revival of pragmatism: New essays on social thought, law, and culture (pp. 62-71). Durham, NC: Duke University Press.

Raz, J. (1990). Practical reason and norms. Princeton, NJ: Princeton University Press.

Roberts, J. T. (1982). Accountability in Athenian government. Madison, WI: University of Wisconsin Press.

Roberts, R. N. (1992). Conflict of interest regulation, employees' rights, and the constitution. Public Administration Quarterly, 16 (3), 344367.

Roethlisberger, F. J. (1941). Management and morale. Cambridge, MA: Harvard University Press.

Rohr, J. A. (1989). Ethics for bureaucrats: An essay on law and values $\left(2^{\text {nd }}\right.$ ed.). New York: Marcel Dekker.

Rohr, J. A. (1998). Public service, ethics, and constitutional practice. Lawrence, KS: University Press of Kansas.

Romzek, B. S. (1985). Work and nonwork psychological involvements: The search for linkage. Administration \& Society, 17 (2), 257-281.

Romzek, B. S. (1989). Personal consequences of employee commitment. Academy of Management Journal, 32 (3), 649-661.

Romzek, B. S. (2000). Accountability of congressional staff. Journal of Public Administration Research and Theory, 10 (2), 413-446.

Romzek, B. S., \& Dubnick, M. J. (1987). Accountability in the public sector: Lessons from the challenger tragedy. Public Administration Review, 47 (3), 227-238.

Romzek, B. S., \& Dubnick, M. J. (1994). Issues of accountability in flexible personnel systems. In Ingraham, P.W., \& Romzek, B.S. (Eds.). New paradigms for government: Issues for the changing public service (pp. 263-294). San Francisco, CA: Jossey-Bass.

Romzek, B. S., \& Dubnick, M. J. (2000). Accountability. In Shafritz, J. M. (Ed.). Defining public administration: Selections from the international encyclopedia of public policy and administration (pp. 382-395). Boulder, CO: Westview Press. 
Romzek, B. S., \& Ingraham, P. W. (2000). Cross pressures of accountability: Initiative, command, and failure in the Ron Brown plane crash. Public Administration Review, 60 (3), 240-253.

Rosen, B. (1989). Holding government bureaucracies accountable $\left(2^{\text {nd }}\right.$ ed.). New York: Praeger Publishers.

Rosenbloom, D. H. (1971). Federal service and the constitution: The development of the public employment relationship. Ithaca, NY: Cornell University Press.

Rosenbloom, D. H. (1983). Public administration and law: Bench V. Bureau in the United States. New York: Marcel Dekker.

Rosenbloom, D. H. (1987). Public administrators' liability: Bench V. Bureau in the contemporary administrative state. Public Administration Quarterly, 10 (4), 373-386.

Rosenbloom, D. H. (1988). The public employment relationship and the Supreme Court in the 1980s. Review of Public Personnel Administration, 8 (2), 49-65.

Rosenbloom, D. H., \& Carroll, J. D. (2000). Constitutional competence for public managers: Cases and commentary. Itasca, IL: F. E. Peacock Publishers.

Rourke, F. E. (1992). Responsiveness and neutral competence in American bureaucracy. Public Administration Review, 52(6), 539546.

Schedler, A. (1999). Conceptualizing accountability. In Schedler, A., Diamond, L.J., \& Plattner, M.F. (Eds.). The self-restraining state: Power and accountability in new democracies (pp. 13-28). Boulder, CO: Lynne Rienner Publishers.

Schedler, A., Diamond, L.J., \& Plattner, M.F. (Eds.). (1999). The selfrestraining state: Power and accountability in new democracies. Boulder, CO: Lynne Rienner Publishers.

Scheffler, S. (1994). The rejection of consequentialism: A philosophical investigation of the considerations underlying rival moral considerations (revised ed.). Oxford, UK: Claredon Press.

Schuck, P. H. (1999). The limits of law: Essays on democratic governance. Boulder, CO: Westview Press. 
Dubnick ACCOUNTABILITY AND ETHICS: RECONSIDERING THE

RELATIONSHIPS 439

Scott, M. B., \& Lyman, S. M. (1968). Accounts. American Sociological Review, 33 (1), 46-62.

Sereny, G. (1995). Albert Speer: His battle with truth. New York: Knopf.

Shklar, J. N. (1984). Ordinary vices. Cambridge, MA: Belknap/Harvard University Press.

Shklar, J. N. (1986). Legalism: Law, morals, and political trials. Cambridge, MA: Harvard University Press.

Shklar, J. N. (1990). The faces of injustice. New Haven, CT: Yale University Press.

Sinclair, A. (1995). The chameleon of accountability: Forms and discourses. Accounting, Organizations and Society, 20 (2/3), 219237.

Smiley, M. (1992). Moral responsibility and the boundaries of community: Power and accountability from a pragmatic point of view. Chicago, IL: University of Chicago Press.

Stark, A. (1995). The appearance of official impropriety and the concept of political crime. Ethics, 105 (2), 326-351.

Stewart, R. B. (1975). The reformation of American administrative law. Harvard Law Review, 88, 1669-1813.

Stone, C. D. (1975). Where the law ends: The social control of corporate behavior. New York: Harper Torchbooks.

Stryker, S., \& Macke, A. S. (1978). Status inconsistency and role conflict. Annual Review Of Sociology, 4, 57-90.

Sunstein, C. R. (1996). Legal reasoning and political conflict. New York: Oxford University Press.

Sykes, G. M., \& Matza, D. (1957). Techniques of neutralization: A theory of delinquency. American Sociological Review, 22 (6), 664670.

Tavuchis, N. (1991). Mea Culpa: A sociology of apology and reconciliation. Stanford, CA: Stanford University Press.

Tetlock, P. E. (1981). The influence of self-presentation goals on attributional reports. Social Psychology Quarterly, 44 (4), 300-311. 
Tetlock, P. E. (1983). Accountability and complexity of thought. Journal of Personality and Social Psychology, 45 (1), 74-83.

Tetlock, P. E. (1985, September). Accountability: A social check on the fundamental attribution error. Social Psychology Quarterly, 48 (3), 227-236.

Tetlock, P. E. (1983, December). Accountability and the perseverance of first impressions. Social Psychology Quarterly, 46 (4), 285-292.

Tetlock, P. E., \& Kim, J. I. (1987). Accountability and judgment processes in a personality prediction task. Journal of Personality and Social Psychology, 52 (4), 700-709.

Tetlock, P. E., Skitka, L., \& Boettger, R. (1989). Social and cognitive strategies for coping with accountability: Conformity, complexity, and bolstering. Journal of Personality and Social Psychology, 57 (4), 632-640.

Thompson, D. F. (1980). Moral responsibility of public officials: The problem of many hands. American Political Science Review, 74 (4), 905-916.

Thompson, D. F. (1987). Political ethics and public office. Cambridge, MA: Harvard University Press.

Thomson, J. J. (1984). Remarks on causation and liability. Philosophy And Public Affairs, 13 (2), 101-133.

Thruber, K. T., Jr. (1993). Big, little, littler: Synthesizing hatch act-based political activity legislation research. Review of Public Personnel Administration, 13 (1), 38-51.

Turner, R. H. (1978, July). The role and the person. American Journal of Sociology, 84 (1), 1-23.

Wamsley, G. L., Bacher, R. N., Goodsell, C. T., Kronenberg, P. S., Rohr, J. A., Stivers, C. M., White, O. F., \& Wolf, J. F. (1990). Refounding public administration. Newbury Park, CA: Sage Publications.

Wamsley, G. L., \& Wolf, J. F. (Eds.). (1996). Refounding democratic public administration: Modern paradoxes, postmodern challenges. Thousand Oaks, CA: Sage Publications. 
Dubnick ACCOUNTABILITY AND ETHICS: RECONSIDERING THE RELATIONSHIPS 441

Waterman, R. W., \& Meier, K. J. (1998). Principalagent models: An expansion? Journal of Public Administration Research and Theory, 8 (2), 173-202.

Weber, M. (1978). Economy and society: An outline of interpretive sociology (Volume 1). Berkely, CA: University of California Press.

Whyte, Jr., W. H. (1956). The organization man. Garden City, NY: Doubleday Anchor.

Wood, B. D., \& Waterman, R. W. (1994) Bureaucratic dynamics: The role of bureaucracy in a democracy. Boulder, CO: Westview Press.

Woodward, B. (1991). The commanders. New York: Simon and Schuster.

Yarkin-Levin, K. (1983). Anticipated interaction, attribution, and social interaction. Social Psychology Quarterly, 46 (4), 302-311. 